\title{
Bioethanol used as topical antiseptics: Pretreatment optimization of bioethanol production from tobacco industrial waste \\ Bekti Palupi ${ }^{1}$, Boy Arief Fachri ${ }^{1}$, Istiqomah Rahmawati ${ }^{1}$, Ari Susanti ${ }^{1}$, Felix Arie Setiawan ${ }^{1}$, Praptiningsih Gamawati Adinurani², Maizirwan $\mathrm{Mel}^{3}$
}

\author{
${ }^{1}$ Department of Chemical Engineering, University of Jember, Indonesia \\ ${ }^{2}$ Department of Agrotechnology, Merdeka University of Madiun, Indonesia \\ ${ }^{3}$ Department of Biotechnology Engineering, International Islamic University Malaysia, Malaysia
}

Corresponding author:

Bekti Palupi (bekti.palupi@unej.ac.id)

\begin{abstract}
:
Bioethanol can be used for biosolvents and antiseptics material in the pharmaceutical industry. With the abundance of tobacco production in Jember, East Java, Indonesia, tobacco stalks become a promising biomass raw material for bioethanol. The purpose of this study was to determine the effect of temperature on the pretreatment process of bioethanol production. Settings and Design of this study using Conventional pretreatment with batch system. The materials used in this study include industrial tobacco waste, $\mathrm{HCl}, \mathrm{H}_{2} \mathrm{SO}_{4}$, aquadest, filter paper, and aluminum foil. The pretreatment method used is chemical methods. The effect of pretreatment temperature was analyzed on the pretreatment process for the optimization of bioethanol production. Statistical analysis used a percentage frequency distribution. The test results of cellulose with $\mathrm{H}_{2} \mathrm{SO}_{4}$ solvents are $6.99 \%$ at temperature $100{ }^{\circ} \mathrm{C}, 6.60 \%$ at temperature $120{ }^{\circ} \mathrm{C}$, and $4.47 \%$ at temperature $140{ }^{\circ} \mathrm{C}$. The test results of cellulose with $\mathrm{HCl}$ solvents are $6.00 \%$ at temperature $100{ }^{\circ} \mathrm{C}, 6.23 \%$ at temperature $120{ }^{\circ} \mathrm{C}$, and $5.66 \%$ at temperature $140{ }^{\circ} \mathrm{C}$. Conclusions of this study, the optimum temperature in the pretreatment process with $\mathrm{H}_{2} \mathrm{SO}_{4}$ for the temperature range $100{ }^{\circ} \mathrm{C}$ to $140{ }^{\circ} \mathrm{C}$ is $100{ }^{\circ} \mathrm{C}$, with the cellulose content produced as much as $6.99 \%$. The optimum temperature in the pretreatment process with $\mathrm{HCl}$ for the temperature range $100{ }^{\circ} \mathrm{C}$ to $140{ }^{\circ} \mathrm{C}$ is $120{ }^{\circ} \mathrm{C}$, with the cellulose content produced as much as $6.23 \%$.
\end{abstract}

Keywords: $2^{\text {nd }}$ generation bioethanol, pretreatment process of bioethanol, tobacco stalks, waste to pharmaceutical, zero waste.

How to cite this article: Palupi et al. (2020): Bioethanol used as topical antiseptics: Pretreatment optimization of bioethanol production from tobacco industrial waste, Ann Trop \& Public Health; 23(S8): 1213-1219.

DOI: http://doi.org/10.36295/ASRO.2020.2384

\section{Introduction}

Bioethanol is an option because it is environmentally friendly and its raw materials derived from bioresources are abundantly available in Indonesia. Bioethanol has been developed up to the $4^{\text {th }}$ generation. First generation bioethanol uses raw materials of sugar cane and cassava starch, the second generation comes from biomass containing cellulose, the third generation is made from algae, and the fourth generation is produced from transgenic biomass ${ }^{(1)}$. In Indonesia, bioethanol currently being developed is $1^{\text {st }}$ and $2^{\text {nd }}$ generation. Raw materials for the first generation of bioethanol compete with foodstuffs so that $2^{\text {nd }}$ generation of bioethanol is the solution to the problem. The second generation of bioethanol can be developed from water hyacinth, rice straw, sugar cane bagasse, oil palm bunches skin, sweet orange peel, and other biomass wastes. One of the biomass raw materials that can be utilized for bioethanol production is the tobacco industry waste ${ }^{(2)}$. Indonesia is a country with an abundance of bioresources, both from agriculture and plantations. One of the abundant bioresources of plantations in Indonesia is tobacco. The biggest contributor to tobacco production in Indonesia is East Java Province, including Jember Regency. Based on 2017 Indonesian Plantation Statistics, tobacco production in Jember is $3.949 \mathrm{t}$. With the abundance of tobacco sources, there are many tobacco industries in the Jember region. The production process in the tobacco industry produces tobacco stalks as waste because what is used for production is the part of the leaves. At present, the issue of waste and environmental pollution is a concern. Tobacco industries are expected to be able to handle waste without polluting the surrounding environment. One effort that can be done to deal with tobacco industry waste is to convert tobacco industry waste into bioethanol so that it has added value 
and can be an alternative topical antiseptic. Utilization of tobacco industry waste for bioethanol raw material is included in the category of development of the $2^{\text {nd }}$ generation of bioethanol. The second generation of bioethanol production sourced from biomass waste is a solution from the $1^{\text {st }}$ generation that uses food as raw material. Topical antiseptics are widely used by health professionals in hospitals, clinics, health centers, doctor's offices, outpatient hospitals, nursing homes, the health industry, the chemical industry, and the food industry. Antiseptics contain various active ingredients, including ethanol ${ }^{(3-7)}$. The use of antiseptics is a standard operating procedure for these industries ${ }^{(8)}$. Ethanol-based topical antiseptics, usually called Alcohol-Based Hand Sanitizers (ABHS), are routinely used as skin hygiene standards to reduce the presence of living bacteria on the skin and are part of hygiene procedures in the health care department ${ }^{(9)}$. Today, antiseptics are an important part of medical treatment. In all medical fields such as wound treatment, treatment of burns, prophylaxis before surgery, and diagnostic procedures skin disinfectants are routinely used ${ }^{(10)}$. Topical antiseptics are antimicrobial agents that can kill or reduce the number of microorganisms ${ }^{(11)}$. However, they have commonly used on wounds to prevent or treat infection ${ }^{(12)}$, the benefits of antiseptic fluid irrigation have received little scientific study ${ }^{(13)}$. The safety of the use from topical ethanol antiseptics is still a scientific debate. Many researchers have shown that skin damage is caused by alcohol use, a detrimental effect on some internal organs such as the liver, central nervous system, and other body systems ${ }^{(14)}$. On the other hand, many researchers say that the use of topical antiseptics is safe ${ }^{(15-19)}$. The process of bioethanol production from tobacco industry waste through several stages of the process. In general, the process of making bioethanol includes pretreatment, hydrolysis, fermentation, and distillation. The biomass pretreatment stage aims to separate lignin, cellulose, and hemicellulose before being processed at the next stage ${ }^{(20-21)}$. The results of the optimal separation of cellulose from lignin are expected to produce optimal bioethanol production as well. The stage of pretreatment from tobacco industry waste is one of the important stages because it will affect the result of bioethanol production ${ }^{(22-23)}$. Therefore, this study will optimize the chemical pretreatment method to separate lignin, cellulose, and hemicellulose. Chemical method pretreatment was chosen because it has several advantages compared to other methods such as low cost, available material, fast time, and does not require large energy.

\section{Materials and methods \\ Materials:}

The materials used in this study include industrial tobacco waste, $\mathrm{HCl}, \mathrm{H}_{2} \mathrm{SO}_{4}$, aquadest, filter paper, and aluminum foil.

\section{Metods:}

Sample Preparation

Sample preparation includes biomass raw materials derived from industrial tobacco waste are mashed first with a chopper. After being smoothed, the raw material is sifted with a 60 mesh sieve so that a uniform size is obtained. Then, weigh the raw materials. The last step on sample preparation is dried the raw material in an oven for $1 \mathrm{~h}$ at a temperature of $60{ }^{\circ} \mathrm{C}$ to $70{ }^{\circ} \mathrm{C}$.

\section{Pretreatment with Chemical Methods}

Pretreatment is carried out by put $1 \mathrm{~g}$ of sample into a glass beaker and soak it with $10 \mathrm{~mL} 4 \% \mathrm{HCl}$. After that, heat in temperatures of $100{ }^{\circ} \mathrm{C}, 120^{\circ} \mathrm{C}$, and $140{ }^{\circ} \mathrm{C}$ for $30 \mathrm{~min}$. Analysis of lignin, cellulose, and hemicellulose in the sample so that the optimum temperature is obtained. Repeat steps one to three for pretreatment with $4 \% \mathrm{H}_{2} \mathrm{SO}_{4}$.

\section{Analysis of Lignin, Cellulose, and Hemicellulose}

Analysis of lignin, cellulose, and hemicellulose was carried out by the Chesson method. The test methods were added $150 \mathrm{~mL}$ of distilled water $1 \mathrm{~g}$ to $2 \mathrm{~g}$ of dry sample (weight a) and heated at $100{ }^{\circ} \mathrm{C}$ for 2 hr. Filtered with filter paper and residues rinsed with distilled water. The residue is then dried in an oven until the weight is constant and then weighed (weight $b$ ). The residue was added with $150 \mathrm{~mL}$ of $1 \mathrm{~N} \mathrm{H}_{2} \mathrm{SO}_{4}$, then refluxed with a water bath for $1 \mathrm{~h}$ at $100{ }^{\circ} \mathrm{C}$. The results are filtered and examined until neutral, and the residue is dried until the weight is constant. Weight weighed (weight c). Dry residue added $100 \mathrm{~mL}$ of $72 \% \mathrm{H}_{2} \mathrm{SO}_{4}$ and soaked at room temperature for $4 \mathrm{~h}$. Added $150 \mathrm{~mL}$ of $1 \mathrm{~N} \mathrm{H}_{2} \mathrm{SO}_{4}$ and refluxed at $100{ }^{\circ} \mathrm{C}$ with a water bath for $2 \mathrm{~h}$. The residue is filtered and washed with distilled water until it is neutral. The residue is then heated in an oven with a temperature of $105{ }^{\circ} \mathrm{C}$ until it is constant weight and weighed (weight $\mathrm{d}$ ). Then the residue is ignored by heating at a temperature of $600{ }^{\circ} \mathrm{C}$ for $4 \mathrm{~h}$ to $6 \mathrm{~h}$ and weighed (weight e). 
After testing the following procedure, the levels of lignin, cellulose, and hemicellulose can be calculated using the following formula (1);(2);(3):

$$
\begin{aligned}
& \frac{d-e}{a} \times 100 \% \\
& \frac{c-d}{a} \times 100 \% \\
& \frac{b-c}{a} \times 100 \%
\end{aligned}
$$

\section{Data analysis:}

To find out the optimum temperature, the results of pretreatment (cellulose) vs. temperature were graphed. The optimum temperature can be seen from the optimum pretreatment results.

\section{Results}

Tobacco stem waste is obtained from PT Mangli Djaya Raya and Farmer's Group of Karunia Tembakau in Jember, Indonesia. The tobacco stalks that has been obtained is then crushed and dried. The crushed sample is then smoothed and uniformized using a 60 mesh size sieve. The results of the sieve can be seen in figure 1 as follows.

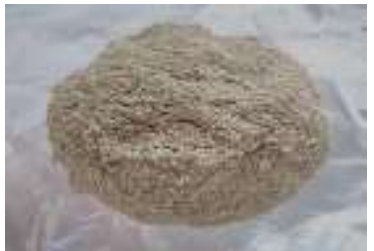

Figure 1. Sample size 60 mesh

The sample is then heated at $60{ }^{\circ} \mathrm{C}$ for $1 \mathrm{~h}$ to remove the water content that is still present in the sample. The sample can be seen in figure 2 .

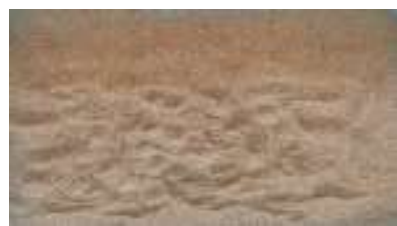

Figure 2. Sample after in the oven

\section{Pretreatment:}

The earliest stages of the bioethanol production process from biomass are pretreatment. The objectives of the pretreatment process on bioethanol production are (i) to reduce the size of material in physical terms (24), (ii) providing exposure to components (hemicellulose, cellulose, lignin) before the hydrolysis process (25), (iii) providing better access to hydrolysis for enzymes to hydrolyze carbohydrates into fermentable sugars in the next enzymatic hydrolysis method ${ }^{(26)}$ and (iv) reduction in the degree of crystallinity of the cellulose matrix ${ }^{(27)}$. One method that is often used in pretreatment processes is the chemical method. The type of acid that is often used for chemical methods pretreatment are $\mathrm{H}_{2} \mathrm{SO}_{4}, \mathrm{HCl}$, and $\mathrm{HNO}_{3}{ }^{(28)}$. The purpose of the pretreatment process is to break down the lignin structure and change the crystal structure of cellulose so that acids or enzymes can easily hydrolyze cellulose ${ }^{(29)}$. Comparison of biomass structures before and after pretreatment can be seen in figure 3 . From figure 3 it is clear that lignin, cellulose, and hemicellulose are bound to one another, so pretreatment is needed to break the bond. 


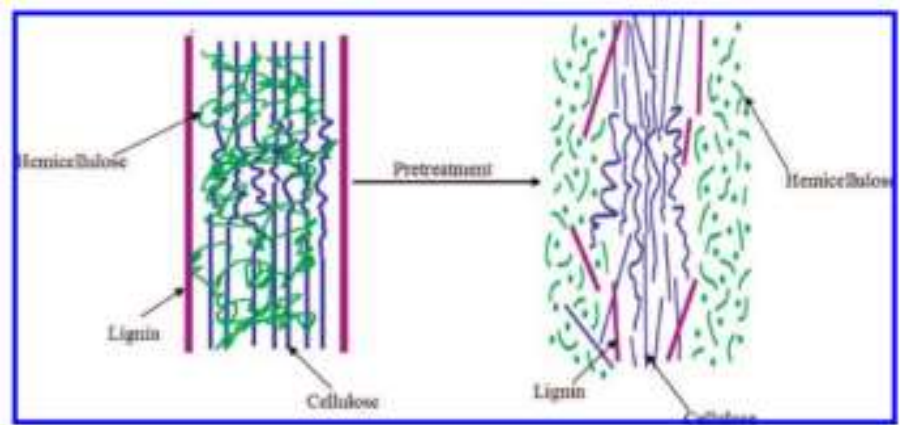

Figure 3. Biomass before and after pretreatment ${ }^{(29)}$

The main constituents of tobacco stalk are lignin, cellulose, and hemicellulose. Cellulose is a polymer that will be hydrolyzed into alcohol. In this study, the pretreatment process of tobacco stems was carried out using chemical

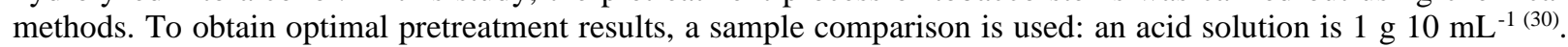
The acid solutions used were $\mathrm{H}_{2} \mathrm{SO}_{4}$ and $\mathrm{HCl} 4 \%{ }^{(31)}$. Samples that have been pretreated with $\mathrm{H}_{2} \mathrm{SO}_{4}$ and $\mathrm{HCl}$ can be seen in figure 4 and figure 5 .

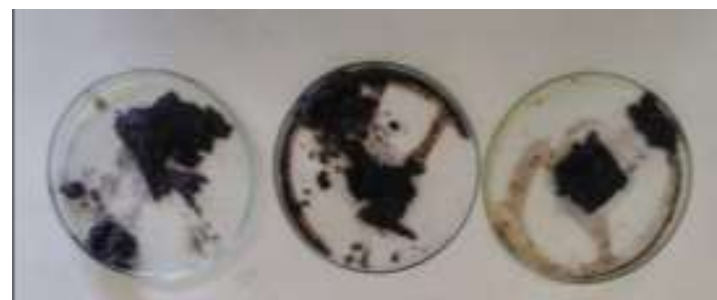

Figure 4. Pretreatment with $\mathrm{H}_{2} \mathrm{SO}_{4}$

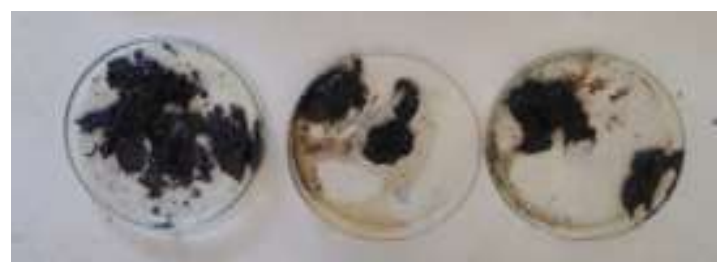

Figure 5. Pretreatment with $\mathrm{HCl}$

\section{Lignin, cellulose and hemicellulose test results:}

Testing of lignin, cellulose, and hemicellulose using the Chesson method. The testing process was carried out at the Bioscience Laboratory of State Polytechnic of Jember. The test results of lignin, cellulose, and hemicellulose with $\mathrm{H}_{2} \mathrm{SO}_{4}$ solvents can be seen in table 1, while the test of lignin, cellulose, and hemicellulose with $\mathrm{HCl}$ solvents can be seen in table 2 .

Table 1. Lignin, cellulose, and hemicellulose test results with $\mathrm{H}_{2} \mathrm{SO}_{4}$

\begin{tabular}{|c|c|c|c|}
\hline Temperature $\left({ }^{\circ} \mathbf{C}\right)$ & Lignin (\%) & Cellulosa (\%) & Hemicellulose (\%) \\
\hline 100 & 3.84 & 6.99 & 2.84 \\
\hline 120 & 2.42 & 6.60 & 4.37 \\
\hline 140 & 2.57 & 4.47 & 3.66 \\
\hline
\end{tabular}

Table 2. Lignin, cellulose, and hemicellulose test results with $\mathrm{HCl}$

\begin{tabular}{|c|c|c|c|}
\hline Temperature $\left({ }^{\circ} \mathbf{C}\right)$ & Lignin (\%) & Cellulosa (\%) & Hemicellulose (\%) \\
\hline 100 & 3.26 & 6.00 & 4.04 \\
\hline 120 & 2.76 & 6.23 & 3.49 \\
\hline 140 & 3.64 & 5.66 & 3.20 \\
\hline
\end{tabular}

\section{Discussion}

Pretreatment for biomass is generally carried out in the temperature range $100{ }^{\circ} \mathrm{C}$ to $140{ }^{\circ} \mathrm{C}^{[32]}$. Acid pretreatment can be carried out at high temperatures $>160{ }^{\circ} \mathrm{C}$ and low temperatures $<160{ }^{\circ} \mathrm{C}^{[29]}$. The effect of temperature on cellulose produced with $4 \% \mathrm{H}_{2} \mathrm{SO}_{4}$ acid solvent can be seen in Figure 6. Based on Table 1, the highest cellulose 
content at $100{ }^{\circ} \mathrm{C}$ is $6.99 \%$. When the temperature was raised to $120{ }^{\circ} \mathrm{C}$, the cellulose level decreased to $6.60 \%$. When the temperature was raised again to $140{ }^{\circ} \mathrm{C}$, the cellulose level decreased to $4.47 \%$. Therefore, the optimum pretreatment temperature with $4 \% \mathrm{H}_{2} \mathrm{SO}_{4}$ in this study was reached at $100{ }^{\circ} \mathrm{C}$.

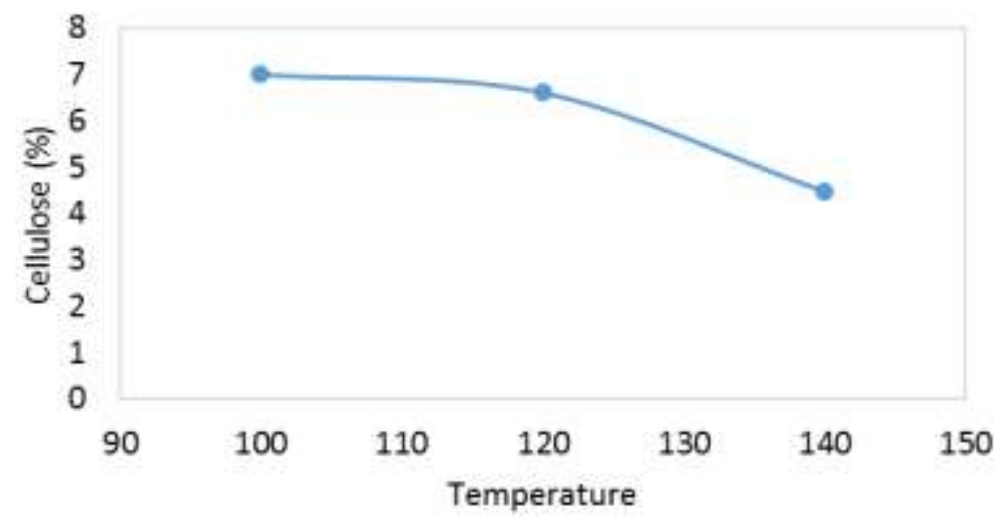

Figure 6. Graph of temperature vs cellulose with $\mathrm{H}_{2} \mathrm{SO}_{4}$ pretreatment

Based on table 1 shows that an increase in temperature indicates a decrease in the amount of lignin and cellulose using sulfuric acid pretreatment method. This condition was analyzed because the magnitude of the acid strength of sulfuric acid $\left(\mathrm{Ka}_{1} 1 \times 10^{3}\right.$ and $\left.\mathrm{Ka}_{2} \quad 1 \times 10^{-2}\right)$ increased temperature instead causing a side reaction namely hydrolysis of cellulose. The magnitude of the temperature will result in greater energy possessed by $\mathrm{H}_{2} \mathrm{SO}_{4}$ molecules where this condition is by the Arrhenius Equation. The amount of energy possessed by $\mathrm{H}_{2} \mathrm{SO}_{4}$ coupled with high acid strength will initiate the pretreatment process better coupled with the presence of side reactions namely the occurrence of the cellulose hydrolysis reaction it self. The Arrhenius Equation is as follows (formula 4):

$$
k=A e^{-\frac{E a}{R T}}
$$

( $\mathrm{k}=$ the rate constant, $\mathrm{A}=$ the frequency factor, $\mathrm{Ea}=$ the activation energy, $\mathrm{R}=$ the gas constant, and $\mathrm{T}=$ the reaction temperature).

The effect of temperature on cellulose content with $4 \% \mathrm{HCl}$ can be seen in Fig. 7. The pretreatment process with $4 \% \mathrm{HCl}$ at $100{ }^{\circ} \mathrm{C}$ resulted in cellulose content of $6.00 \%$. Cellulose content increased to $6.23 \%$ when the temperature was raised to $120{ }^{\circ} \mathrm{C}$, but decreased to $5.66 \%$ when the temperature was raised to $140{ }^{\circ} \mathrm{C}$. Thus, the optimum temperature in the pretreatment process with $4 \% \mathrm{HCl}$ is $120{ }^{\circ} \mathrm{C}$.

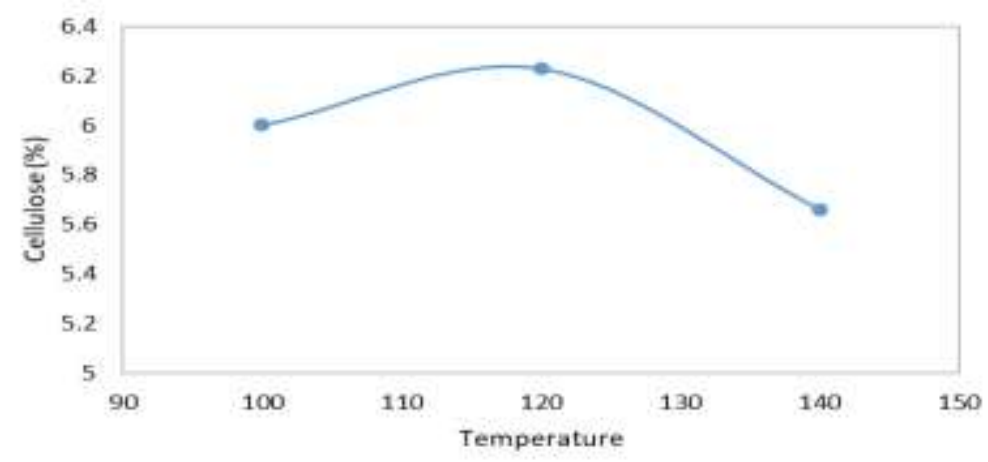

Figure 7. Graph of temperature vs cellulose with $\mathrm{HCl}$ pretreatment.

Based on table 2 shows that at a temperature of $100{ }^{\circ} \mathrm{C}$, the pretreatment conditions were not optimal as indicated by the magnitude of lignin levels and small cellulose levels. This is because even though the acid strength of acetic acid is high $\left(1.3 \times 10^{6}\right), \mathrm{HCl}$ is only able to ionize $\mathrm{H}+$ ions once. So that with the same volume of addition as the pretreatment method using $\mathrm{H}_{2} \mathrm{SO}_{4}$, higher energy is needed to produce optimum conditions from the pretreatment process. The amount of energy needed in the process will be proportional to the amount of temperature involved 
during the process. This condition is by the Arrhenius equation where the amount of energy needed during the chemical reaction process is proportional to the temperature involved during the process. The greater the temperature involved during the pretreatment process it turns out that the pretreatment condition is not optimal. This is indicated at temperatures of $140{ }^{\circ} \mathrm{C}$ where the amount of cellulose is significantly reduced. This is because of the magnitude of the temperature results in the high energy possessed by the molecule $\mathrm{HCl}$ so that the reaction does not only occur between lignin and $\mathrm{HCl}$ but also cellulose with $\mathrm{HCl}$.

\section{Conclusions}

The conclusions obtained from this study are:

i. The optimum temperature in the pretreatment process with $\mathrm{H}_{2} \mathrm{SO}_{4}$ for the temperature range $100{ }^{\circ} \mathrm{C}$ to $140{ }^{\circ} \mathrm{C}$ is $100{ }^{\circ} \mathrm{C}$, with the cellulose content produced as much as $6.99 \%$.

ii. The optimum temperature in the pretreatment process with $\mathrm{HCl}$ for the temperature range $100{ }^{\circ} \mathrm{C}$ to $140{ }^{\circ} \mathrm{C}$ is $120^{\circ} \mathrm{C}$, with the cellulose content produced as much as $6.23 \%$.

\section{Acknowledgement}

The author is grateful to the University of Jember for research support through the grants of beginner lecturers.

\section{References}

1. Kuhad RC, Gupta R, and Khasa YP. Bioethanol production from Lantana camara L. (Red Sage): pretreatment, saccharification and fermentation. Bioresource Technology. 2010; 101: p. 8348-8354.

2. Poltronieri P. Tobacco seed oil for biofuels. Biotransformation of Agriculture Waste and by-Products. CNR-ISPA. 2016; p. 161-187.

3. Kampf G, Pitten FA, Heeg P, and Christiansen B. Efficacy of two ethanol-based skin antiseptics on the forehead at shorter application times. BMC Microbiology. 2007; 7(85): p. 1-7.

4. Bernardo THL, Verissimo RCSS, Alvino V, Araujo MGS, Santos RFP, Viana MDM, et al. Antimicrobial analysis of an antiseptic made from ethanol crude extracts of P. granatum and E. uniflora in wistar rats against Staphylococcus aureus and Staphylococcus epidermidis. The Scientific World Journal. 2015; (ID 751791): 1-7.

5. Reichel M, Heisig P, Kohlmann T, and Kampf G. Alcohols for skin antisepsis at clinically relevant skin sites. Antimicrobial Agents and Chemotherapy. 2009; 53(11): p. 4778-4782.

6. Weber DJ, Rutala WA, and Sickbert-Bennett EE. Outbreaks associated with contaminated antiseptics and disinfectants. Antimicrobial Agents and Chemotherapy, 2007; 51(12): p. 4217-4224.

7. Rotter ML. Hand washing and hand disinfection. In: Mayhall, C.G, editor. Hospital Epidemiology and Infection Control, $4^{\text {st }}$ ed. Lippincott Williams \& Wilkins. 2011; p. 1365-83.

8. Johnson L, Grueber S, Schlotzhauer C, Phillips E, Bullock P, Basnett J, et al. A multifactorial action plan improves hand hygiene adherence and significantly reduces central line-associated bloodstream infections. American Journal of Infection Control. 2014; 42: p. 1146-1151.

9. Maier A, Ovesen JL, Allen CL, York RG, Gadagbui BK, Kirman CR, et al. Safety assessment for ethanol-based topical antiseptic use by health care workers: Evaluation of developmental toxicity potential. Regulatory Toxicology and Pharmacology Journal. 2015; 73: p. 248-264.

10. Langer S, Salakdeh MS, Goertz O, Steinau U, Steinstraesser L, and Homann HH. The impact of topical antiseptics on skin microcirculation. European Journal of Medical Research. 2004; 9: p. 449-454.

11. Atiyeh BS, Dibo SA, and Hayek SN. Wound cleansing, topical antiseptics and wound healing. International Wound Journal. 2009; 6: p. 420-430.

12. Drosou A, Falabella A, and Kirsner RS. Antiseptics on wounds: An area of controversy. Wounds. 2003; 15(5): p. 149-166.

13. Smith RG. A critical discussion of the use of antiseptics in acute traumatic wounds. Journal American Podiatric Medical Association. 2005; 95(2): p. 148-153.

14. Pendlington RU, Whittle E, Robinson JA, and Howes D. Fate of ethanol topically applied to skin. Food and Chemical Toxicology. 2001; 39(2): p. 169-174.

15. Kramer A, Below H, Bieber N, Kampf G, Toma CD, Huebner NO, et al. Quantity of ethanol absorption after excessive hand disinfection using three commercially available hand rubs is minimal and below toxic levels for humans. BMC Infectious Diseases. 2007; 7(117).

16. Kirschner MH, Lang RA, Breuer B, Breuer M, Gronover CS, Zwingers T, et al. Transdermal resorption of an ethanol- and 2-propanol-containing skin disinfectant. Langenbeck's Archives of Surgery. 2007; 394: p. 151-157.

17. Schaefer H, and Redelmeier TE. Safety assessment of cosmetics. In Schaefer H, and Redelmeier TE, editors. Skin barrier: Principles of percutaneous absorption. Basel: Karger. 1996; p. 237-249. 
18. Andersen A. Final report of the safety assessment of Alcohol Denat., including SD alcohol 3-A, SD alcohol 30, SD alcohol 39, SD alcohol 39-B, SD alcohol 39-C, SD alcohol 40, SD alcohol 40-B, and SD alcohol 40-C, and the denaturants, quassin, brucine sulfate/brucine, and denatonium benzoate. International Journal of Toxicology. 2008; 27(1): p. 1-43.

19. De Vasconcelos SM, Santos AM, and Rocha GJ, Souto-Maior AM. Diluted phosphoric acid pretreatment for production of fermentable sugars in a sugarcane-based biorefinery. Bioresoure Technology. 2013; 135: p. 46-52.

20. Vancov T, Schneider RCS, Palmer J, Mcintosh S, and Stuetz R. Potential use of feedlot cattle manure for bioethanol production. Bioresource Technology. 2015; 183: p. 120-128.

21. Akpinar O, Erdogan K, Bakir U, and Yilmaz L. Comparison of acid and enzymatic hydrolysis of tobacco stalk xylan for preparation of xylooligosaccharides. LWT - Food Science and Technology. 2010; 43(1): p. 119-125.

22. Shakhes J, Marandi MB, Zeinaly F, Saraian A, and Saghafi T. Tobacco residuals as promising lignocellulosic materials for pulp and paper industry. Bioresources. 2011; 6(4): p. 4481-4493.

23. Graf A., and Koehler T. Oregon cellulose-ethanol study: An evaluation of the potential for ethanol production in Oregon using cellulose based feedstocks. Oregon: Office of Energy, Inc Bryan \& Bryan, Celilo Group, and National Renewable Energy Laboratory (U.S.). 2000. 30 p.

24. Mosier N, Wyman C, Dale B, Elander R, Holtzapple Y, and Ladisch M. Features of promising technologies for pretreatment of lignocellulosic biomass. Bioresour Technology. 2005; 96(6): p. 673-686.

25. Patel S, and Onkarappa R. Funkal pretreatment studies on rice husk and bagasse for ethanol production. Electronic Journal of Environmental, Agricultural and Food Chemistry. 2007; 6(4): p. 1921-1926.

26. Sanchez Ó, and Cardona C. Trends in biotechnological production of fuel ethanol from different feedstocks. Bioresour Technology. 2008; 99(13): p. 5270-5295.

27. Barakat A, De Vries H, and Rouau X. Dry fractionation process as an important step in current and future lignocellulose biorefineries: A review. Bioresour Technology. 2013; 134: p. 362-373.

28. Kumar P, Barrett DM, Delwiche MJ, and Stroeve P. Methods for pretreatment of lignocellulosic biomass for efficient hydrolysis and biofuel production. American Chemical Society. 2009; 48(8): p. 3713-3729.

29. Schneider RCS, Anacker LA, Szarblewski MS, Silva LFF, Moraes MSA, and Corbellini VA. Bioethanol production from residual tobacco stalks. Current Journal of Applied Science and Technology. 2017; 6(24): p. 1-9.

30. Temitayo C, Ghosh MD, Karyala P, Kokila S, and Sravani I. Tobacco-a platform for efficient biofuel production: pretreatment to bioethanol production from lignocellulosic biomass of tobacco. Ecology, Pollution and Enviromental Science. 2018; 1(2): p. 29-33.

31. Pedersen M, Johansen KS, and Meyer AS. Low temperature lignocellulose pretreatment: Effects and interactions of pretreatment $\mathrm{pH}$ are critical for maximizing enzymatic monosaccharide yields from wheat straw. Biotechnology for Biofuels. 2011; 4: p. 1-10. 